\title{
MRI does not detect acetabular osteolysis around metal-on-metal Birmingham THA
}

\author{
Wenzel Waldstein · Tom Schmidt-Braekling • \\ Friedrich Boettner
}

Received: 9 January 2014 / Published online: 18 May 2014

(C) The Author(s) 2014. This article is published with open access at Springerlink.com

\begin{abstract}
Objective Osteolysis has not been recognized as a common failure mode of the Birmingham modular metal-onmetal (MoM) total hip arthroplasty (THA). The clinical value of metal artifact reduction sequence (MARS) magnetic resonance imaging (MRI) to assess the periprosthetic soft tissue is well documented; however, the appropriate image modalities to detect periacetabular osteolysis remain unclear.

Case summary Eleven patients with periacetabular osteolysis within 3-6 years after uncemented Birmingham modular MoM THA with a synergy stem are presented. All 11 patients received corresponding standardized AP pelvis radiographs, high-quality MARS MRIs and CT scans with a metal artifact reduction sequence. While periacetabular osteolysis around MoM THA was not detected on MARS MRI in ten patients, CT imaging identified osteolysis in all patients. Periacetabular osteolysis appears to be a failure mechanism of the Smith \& Nephew Birmingham MoM THA.

Discussion There is no evidence in the literature to support the effectiveness of MARS MRI to detect periacetabular osteolysis around cobalt chromium alloy metal-on-metal total hip arthroplasties. Osteolysis due to corrosion-related
\end{abstract}

\footnotetext{
W. Waldstein $\cdot$ T. Schmidt-Braekling $\cdot$ F. Boettner $(\bowtie)$ Adult Reconstruction and Joint Replacement Division, Hospital for Special Surgery, Weill Medical College of Cornell University, 535 East 70th Street, New York, NY 10021, USA

e-mail: boettnerf@hss.edu

W. Waldstein

e-mail: WaldsteinW@hss.edu

T. Schmidt-Braekling

e-mail: SchmidtB@hss.edu
}

particles seems to be one of the primary modes of failure in modular MoM THA.

Conclusions MRI is not a sensitive test to identify periacetabular osteolysis. The authors recommend CT for the screening of implants with this failure mode. Our study suggests that patients with a Birmingham modular MoM THA are at increased risk to develop acetabular osteolysis and should be carefully monitored for this failure mode.

Keywords Periacetabular osteolysis - Metal-on-metal · Total hip arthroplasty $\cdot$ Screening $\cdot$ MRI $\cdot$ CT

\section{Introduction}

The postulated advantages of large metal-on-metal articulations are improved range of motion, increased joint stability [1, 2] and less volumetric wear debris compared to standard metal-on-polyethylene bearing surfaces [3, 4]. Well-designed and properly positioned [5] metal-on-metal hip resurfacings have shown excellent clinical results for selected patients at 10 years [6-8]. However, the outcome of metal-on-metal total hip arthroplasty (THA) has been less predictable and some have been withdrawn from the market because of high failure rates [9]. Modular metalon-metal (MoM) THAs consist of an acetabular component identical to hip resurfacings, a femoral component as in standard THA and a large $(>36 \mathrm{~mm})$ metal head that fits the metal socket. In some systems, the stem and head are connected through a modular sleeve to adjust for different neck lengths.

Early implant failure due to adverse local soft-tissue reactions (aseptic lymphocytic vasculitis-associated lesions (ALVAL) [10]) has been reported for some MoM resurfacings and total hips arthroplasties [11]. Recently, 
Table 1 Demographics, implant size, implant position, and clinical findings of the 10 patients

\begin{tabular}{|c|c|c|c|c|c|c|c|c|c|c|}
\hline Patient & Sex & Age (years) & Side & $\begin{array}{l}\text { Head size } \\
(\mathrm{mm})\end{array}$ & $\begin{array}{l}\text { Implant } \\
\text { survival } \\
\text { (months) }\end{array}$ & $\begin{array}{l}\text { Inclination } \\
\left({ }^{\circ}\right)\end{array}$ & $\begin{array}{l}\text { Anteversion } \\
\left({ }^{\circ}\right)\end{array}$ & $\begin{array}{l}\text { Hip pain } \\
\text { (VAS) }\end{array}$ & $\begin{array}{l}\text { Cobalt } \\
(\mu \mathrm{g} / \mathrm{L})\end{array}$ & $\begin{array}{l}\text { Chromium } \\
(\mu \mathrm{g} / \mathrm{L})\end{array}$ \\
\hline 1 & Male & 84 & Left & 48 & $44(\mathrm{R})$ & 46 & 23 & 0 & 1.5 & $<1$ \\
\hline \multirow[t]{2}{*}{2} & Male & 65 & Right & 48 & $56(\mathrm{R})$ & 47 & 26 & 5 & 14.2 & Not available \\
\hline & & & Left & 46 & 58 & 46 & 13 & 3 & & \\
\hline 3 & Female & 71 & Left & 44 & $51(\mathrm{R})$ & 46 & 23 & 9 & 7.4 & Not available \\
\hline 4 & Male & 66 & Left & 46 & 74 & 45 & 24 & 0 & 3.5 & 2.4 \\
\hline 5 & Male & 45 & Right & 50 & $65(\mathrm{R})$ & 46 & 14 & 0 & 4.8 & 1.1 \\
\hline 6 & Male & 59 & Right & 46 & $53(\mathrm{R})$ & 45 & 22 & 0 & 1.2 & 1.1 \\
\hline 7 & Female & 62 & Left & 42 & 57 & 41 & 21 & 0 & 2.4 & 1.6 \\
\hline 8 & Female & 58 & Right & 44 & $49(\mathrm{R})$ & 50 & 15 & 6 & 6.5 & 1.1 \\
\hline 9 & Male & 59 & Right & 48 & $48(\mathrm{R})$ & 43 & 21 & 2 & 3.1 & 1.5 \\
\hline 10 & Female & 53 & Left & 44 & 41 & 44 & 21 & 1 & 4.4 & 3.9 \\
\hline 11 & Female & 65 & Right & 46 & $61(\mathrm{R})$ & 44 & 22 & 0 & 14.9 & 12.9 \\
\hline
\end{tabular}

$V A S$ visual analog scale, $O$ no pain, 10 most severe pain, $R$ the implant was revised in these patients

periacetabular osteolysis has been described as a reason for revision in modular MoM THA [12-14]. While the clinical value of metal artifact reduction sequence (MARS) magnetic resonance imaging (MRI) in the assessment of periprosthetic soft tissues is well documented [15, 16]; the best image modality to detect periacetabular osteolysis around metal-on-metal implants remains unclear [13, 17-19].

Considering the excellent track record of the Birmingham hip resurfacing (Smith \& Nephew, Memphis, TN) [6, 20] it should be assumed that the Birmingham modular total hip replacement (Smith \& Nephew, Memphis, TN), sharing the same design rationale, should also have excellent long-term results.

The purpose of the present case series is (1) to report on 11 patients with periacetabular osteolysis around a Birmingham modular metal-on-metal total hip arthroplasty (Smith \& Nephew, Memphis, TN, USA) and (2) to report on the best imaging to detect periacetabular osteolysis around this implant.

\section{Case report}

The current case series presents 11 patients (12 hips) who underwent follow-up with conventional radiographs, CT imaging and MRI imaging at 4-6 year after implantation of an uncemented Birmingham modular MoM THA (Birmingham Hip acetabular cup, Birmingham Hip modular head and Synergy stem; Smith \& Nephew, Memphis, TN, USA). These patients are part of a single surgeon follow-up study of which $20 \%$ presented with periacetabular osteolysis. The demographics, implant characteristics and position, and the clinical findings are shown in Table 1. Eight hips were revised at a mean of 53 month after the index procedure. In all revised hips, the modular femoral neck taper junction showed a black color resembling corrosion. The remaining four hips are under follow-up at the time this report was written. All 11 patients received corresponding standardized AP pelvis radiographs, high-quality MARS MRIs at the authors' institution and CT scans with artifact reduction at an independent radiology practice (Table 2). For the MRI and CT scan interpretations, the official radiographic reports of board-certified radiologists blinded to the reading of the respective CTs or MRIs were used. Metal ion levels (cobalt and chromium) were obtained for all patients. Two representative patients (patients 2 and 8 ) were selected for further discussion of the clinical workup, and the radiographic and clinical findings.

\section{Patient 2}

Patient 2 was a 65-year-old man who received bilateral MoM THA in 2008. He presented for his follow-up visits at 1 and 5 months postoperative. The components were well aligned and he was pain free (Fig. 1a). The patient presented again for follow-up at 53 months after the index procedure. On the right side, he reported pain in his thigh for the past 3 months. On the left side, he was asymptomatic. The AP pelvis radiograph suggested periprosthetic lucencies in DeLee [21] zone 1 and 2 on the right side and in zone 1 on left side, respectively (Fig. 1b). The CT of the right hip showed an osteolytic lesion extending $5 \times 1 \mathrm{~cm}$ in the anteromedial acetabulum. On the left hip, CT demonstrated a lesion of $2.2 \times 1 \mathrm{~cm}$ in the anterolateral acetabulum. The corresponding MARS MRI which was obtained 


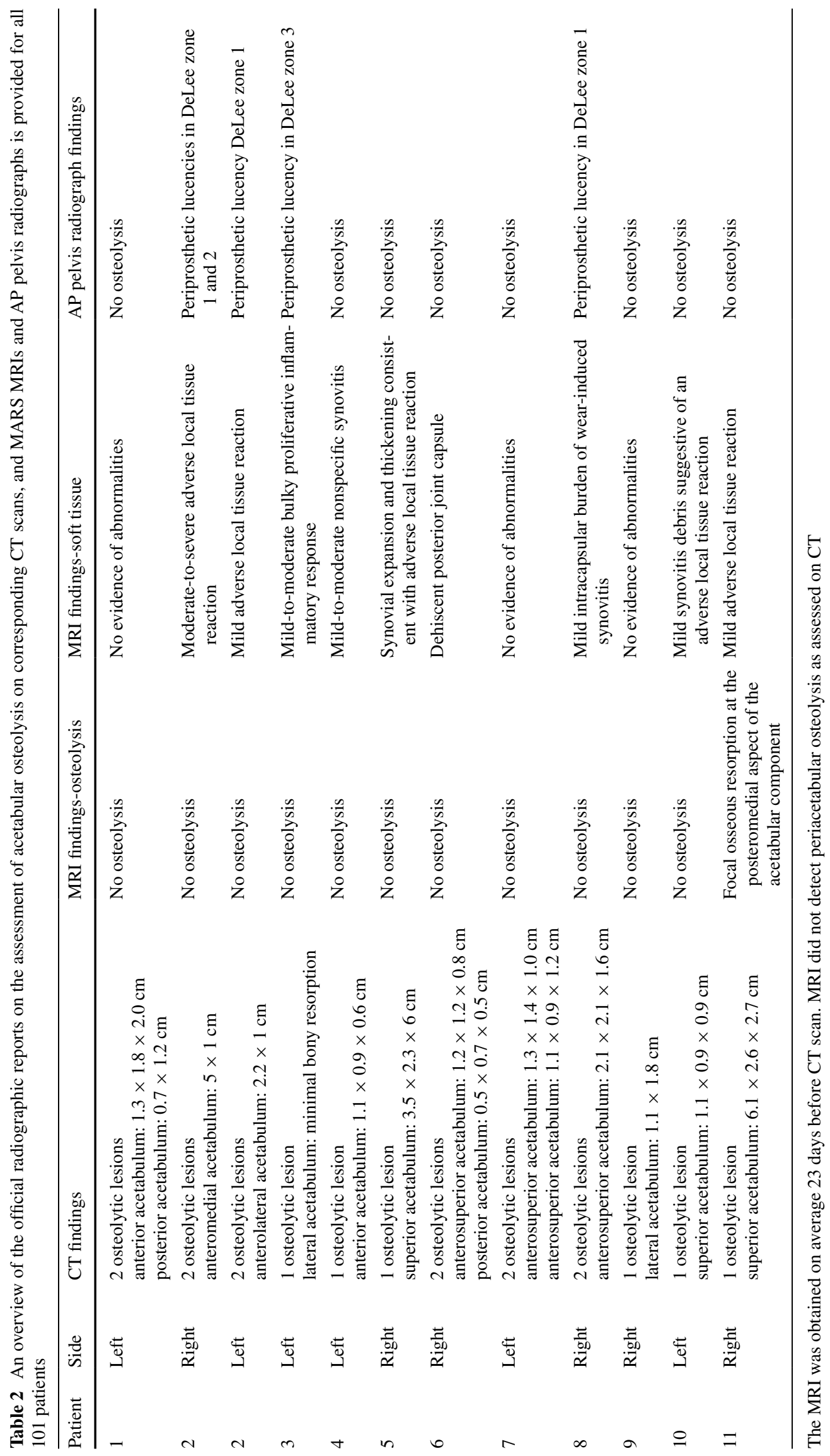



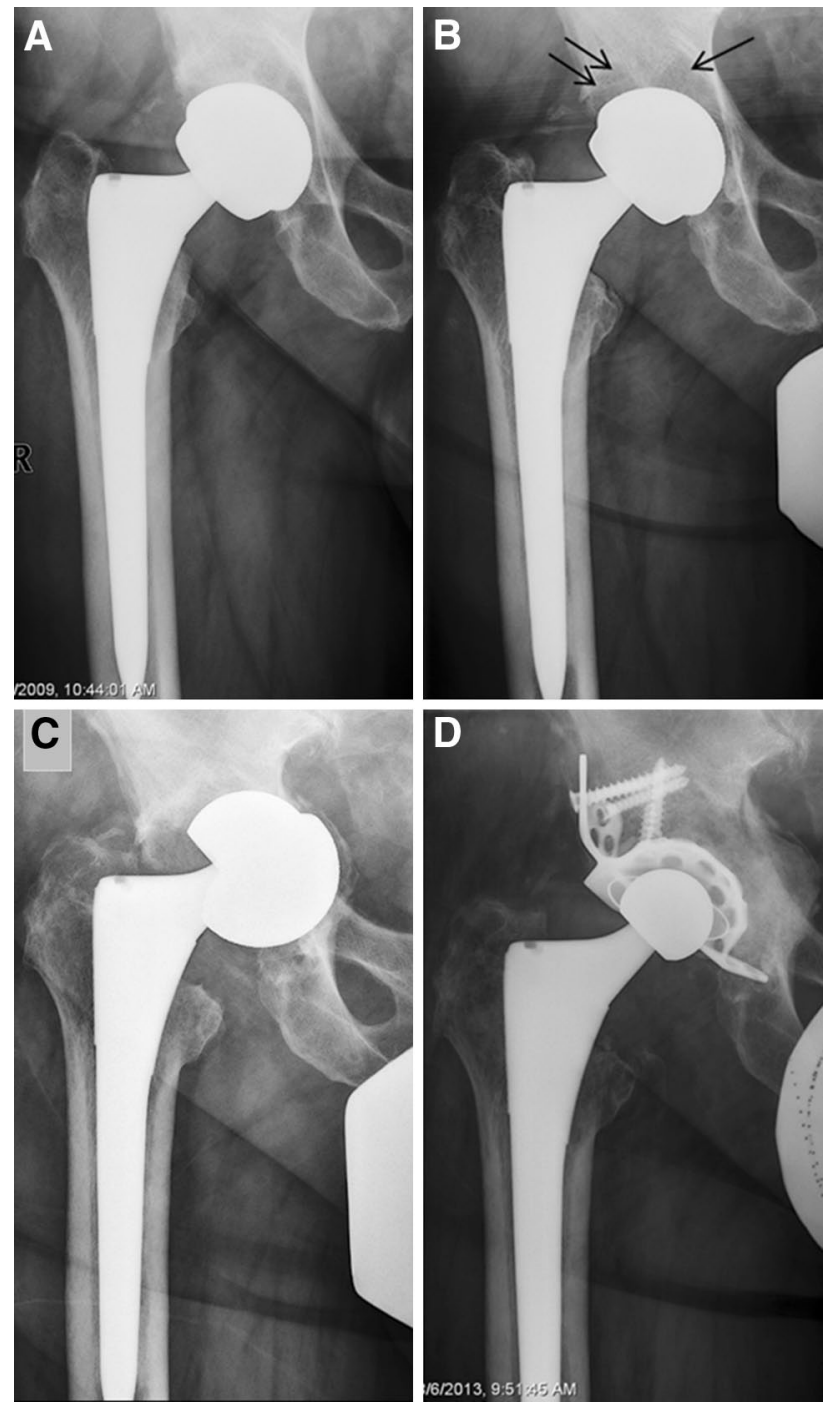

Fig. 1 Standardized anteroposterior (AP) pelvis radiographs showing a Birmingham modular metal-on-metal total hip arthroplasty in a 65-year-old man (patient 2): a well-aligned components were observed 8 weeks after surgery; b periprosthetic lucencies in DeLee zone 1 and 2 were evident 4 months prior to revision surgery (black arrows); $\mathbf{c}$ the loose right cup was seen on the day of revision surgery and $\mathbf{d}$ AP pelvis radiograph 8 weeks after revision surgery demonstrating high-density bone grafting and an acetabular cage with a cemented liner

at the same day did not detect any areas of bone resorption in the acetabulum on either side. The patient was scheduled for bilateral hip revision surgery the following months; however, the surgery was postponed because of signs of cardiac ischemia in the preoperative stress test. After successful stent implantation, hip revision surgery was scheduled 3 months later. On the day of revision surgery, an additional AP pelvis radiograph was obtained which showed a loose and displaced right acetabular component (Fig. 1c). Considering the anticipated difficulty of the surgery and the medical condition of the patient, only the right hip was revised at this point. Intraoperatively, there was a significant amount of fluid collection, but no clear evidence of abnormal soft tissue proliferation. The acetabular component was loose and associated with a large acetabular defect medially, anteriorly and superiorly. The acetabular osteolysis required bone grafting and placement of a cage with a cemented liner (Contour Cage, Reflection cemented Cup, Oxinium head; Smith \& Nephew, Memphis, TN). The postoperative radiographs, showed well-aligned components (Fig. 1d).

\section{Patient 8}

Patient 8 was a 58 -year-old woman with right Birmingham modular metal-on-metal THA implanted in 2009. At 30 months, she presented with right hip pain that had progressively worsened over the course of the last year. Her AP pelvis radiograph showed an area of lucency in DeLee zone 1 on the right side (Fig. 2a). The CT scan identified an osteolytic lesion of $2.1 \times 2.1 \times 1.6 \mathrm{~cm}$ in the anterosuperior acetabular roof (Fig. 2b); however, the MARS MRI did not show periacetabular osteolysis (Fig. 2c). Right hip revision surgery confirmed the osteolytic lesion. A thickened synovium was observed but there was no frank evidence of ALVAL. After removal of the well-fixed acetabular component, the defect was bone grafted, and a hemispherical cup was impacted and secured with screws (Trident, Stryker, Mahwah, NJ; Oxinium head, Smith \& Nephew, Memphis, $\mathrm{TN})$.

\section{Discussion}

The current study is the first to demonstrate that progressive periacetabular osteolysis should be ruled out in patients with the Birmingham modular metal-on-metal THA (Smith $\&$ Nephew, Memphis, TN) and that this failure mode is not detected on MARS MRI. This finding is of high clinical importance as the majority of patients only had mild hip pain and minimal local adverse soft-tissue reactions on MARS MRI and would not have been considered for further aggressive follow-ups. CT imaging identified osteolysis in all patients and allowed for accurate quantification of its size. Periacetabular osteolysis can result in devastating complications as outlined in patient 2 and the authors recommend CT screening for patients with the Birmingham modular metal-on-metal THA. The current findings suggest that CT with metal artifact reduction is a better tool to detect periacetabular osteolysis in MoM THA and should be considered for screening patients with the Birmingham modular metal-on-metal THA and other implants with this failure mode. 
Fig. 2 a Standardized anteroposterior pelvis radiographs demonstrating a Birmingham modular metal-on-metal total hip arthroplasty in a 58-yearold woman (patient 8) with periprosthetic lucency in DeLee zone 1 (black arrows). b Corresponding CT with metal artifact reduction showing periprosthetic osteolysis in the acetabular roof. c Corresponding MARS MRI with no evidence of acetabular osteolysis
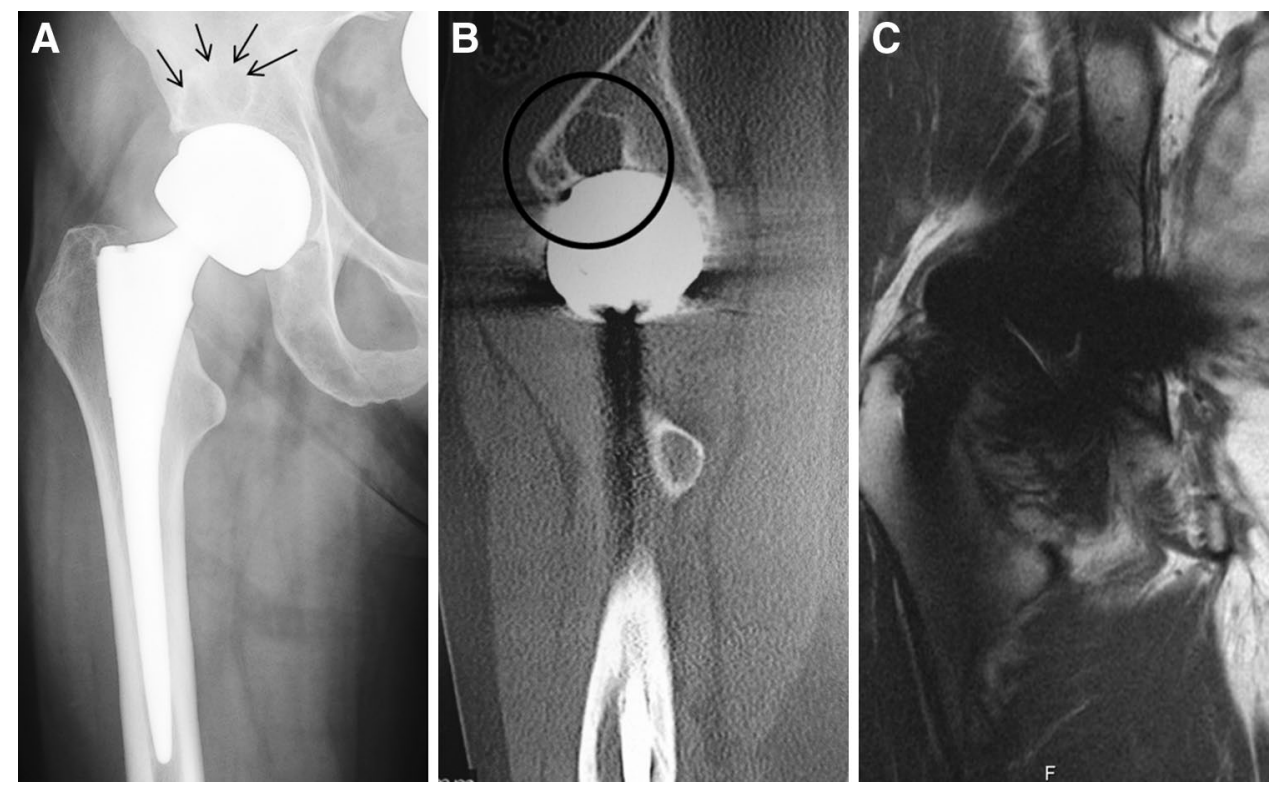

Walde et al. [19] compared the accuracy of radiography, $\mathrm{CT}$ and MRI in assessing periacetabular osteolysis in standard metal-on-polyethylene THA. The authors utilized a previously described cadaver model [22]. Lesions of varying size were created in the ilium, ischium, pubis and osseous posterior rim and filled with ground beef to mimic granuloma tissue. In their study, MRI detected smaller lesions compared to CT, which was not dependent on the location. Yet CT was more accurate in determining the lesion size. The authors concluded that MRI was the most effective tool to detect bone lesions before they might threaten cup stability. To the best of our knowledge this is the only study in the literature directly comparing the effectiveness of MRI and CT to detect periacetabular osteolysis; however, it focuses on a titanium shell with a plastic liner and its findings might not apply to cobalt chromium alloy metalon-metal total hip arthroplasties. The authors' observation has been that for metal-on-metal standard THAs, MRI can fail to detect periacetabular osteolysis. The current findings suggest that CT with metal artifact reduction is a better tool in assessing periprosthetic acetabular osteolysis in MoM THA and to screen implants which are reported to fail secondary to periacetabular osteolysis.

Although, the case series nature of the current paper represents a limitation, osteolytic lesions were detected by MRI in only one patient suggesting that MRI is not a reliable screening tool to assess periacetabular osteolysis in patients with MoM THA. Computed tomography is a better tool to screen patients with implants reported to fail due to periacetabular osteolysis. However, CT screening exposes patients to a 16-fold total effective radiation dose $(23 \mathrm{mSv})$ compared to two views of conventional hip radiographs $(1.4 \mathrm{mSv})$. It must therefore be used with care especially in young female patients. The study also highlights the importance of further investigations comparing the sensitivity and specificity of CT and MRI to detect periacetabular osteolysis in MoM THA.

Previous investigators have described the problems of corrosion at modular femoral neck taper junctions with different metal alloys and the associated increased failure rates [9, 14, 23-30]. Gilbert et al. [25] reported that titanium and its alloys develop a protective layer by passivation from Ti to $\mathrm{TiO}_{2}$. Meyer et al. [14] suggested that instability at the taper leads to micromotion which subsequently damages the passivation layer resulting in galvanic corrosion. Micromotion with small amplitudes due to the instability further causes fretting corrosion [14] which results in increased wear particle debris from the taper junction [14, 27, 28]. Meyer et al. [14] reported that 59 of 114 patients with large head modular MoM THA already showed radiographic signs of osteolysis. The analysis of periprosthetic tissue, sampled at revision surgery, revealed that large amounts of titanium or iron were released [14]. The authors concluded that such corrosion leads to a tissue response that induces osteolysis. The tissue reaction is different from ALVAL reactions [10] as observed in other metal-on-metal implants [14].

The observations in the current case series support Meyer's [14] findings and suggest that the Birmingham modular MoM total hip arthroplasty (Smith \& Nephew, Memphis, $\mathrm{TN}$ ) has a similar failure mechanism. The authors therefore recommend routine CT screening for these patients. The modular neck junctions showed black discoloration in all cases which furthermore supports the concept of osteolysis due to corrosion-related particles as the primary mode of failure in this patient population. 
In the majority of cases, the metal ion levels were within normal limits. Only one patient demonstrated an elevated cobalt level $(14.2 \mu \mathrm{g} / \mathrm{L})$ which still seemed relatively low considering that this patient had bilateral MoM implants. Metal ions released in the corrosion process might therefore be different from cobalt and chromium which would explain the low systemic levels of cobalt and chromium in the current study. Our findings are further supported by Meyer et al. [14] who demonstrated that measured levels for cobalt and chromium as well as nickel in the tissues were low in cases with failed modular MoM THA.

The low systemic levels of cobalt and chromium furthermore suggest minimal wear between the metal bearings of the Birmingham standard total hip arthroplasty system which has previously been reported for the Birmingham hip resurfacing system [31].

In conclusion, MRI failed to detect periacetabular osteolysis in patients with the Birmingham modular MoM THA. Although CT exposes patients to ionizing radiation, it has benefits for the screening for osteolysis in patients with this implant. The current case series suggests that the Birmingham metal-on-metal total hip arthroplasty might fail because of corrosion-related osteolysis. This failure mode should also be considered for the modular R3 metal-on-metal cup with a similar metal sleeve (Smith \& Nephew, Memphis, TN); however, the authors do not have experience with this implant. Surgeons should screen their patients with this implant carefully for periacetabular osteolysis.

Open Access This article is distributed under the terms of the Creative Commons Attribution License which permits any use, distribution, and reproduction in any medium, provided the original author(s) and the source are credited.

\section{References}

1. Berton C, Girard J, Krantz N, Migaud H (2010) The Durom large diameter head acetabular component: early results with a large-diameter metal-on-metal bearing. J Bone Joint Surg Br 92(2):202-208. doi:10.1302/0301-620X.92B2.22653

2. Clarke MT, Lee PT, Villar RN (2003) Dislocation after total hip replacement in relation to metal-on-metal bearing surfaces. J Bone Joint Surg Br 85(5):650-654

3. McKellop HA (2001) Bearing surfaces in total hip replacements: state of the art and future developments. Instr Course Lect 50:165-179

4. Wimmer MA, Fischer A, Buscher R, Pourzal R, Sprecher C, Hauert R, Jacobs JJ (2010) Wear mechanisms in metal-on-metal bearings: the importance of tribochemical reaction layers. J Orthop Res 28(4):436-443. doi:10.1002/jor.21020

5. Grammatopoulos G, Pandit H, Glyn-Jones S, McLardy-Smith P, Gundle R, Whitwell D, Gill HS, Murray DW (2010) Optimal acetabular orientation for hip resurfacing. J Bone Joint Surg Br 92(8):10721078. doi:10.1302/0301-620X.92B8.2419492-B/8/1072

6. Murray DW, Grammatopoulos G, Pandit H, Gundle R, Gill HS, McLardy-Smith P (2012) The ten-year survival of the
Birmingham hip resurfacing: an independent series. J Bone Joint Surg Br 94(9):1180-1186. doi:10.1302/0301-620X.94B9.29462

7. McMinn DJ, Daniel J, Ziaee H, Pradhan C (2011) Indications and results of hip resurfacing. Int Orthop 35(2):231-237. doi:10.1007/s00264-010-1148-8

8. Treacy RB, McBryde CW, Shears E, Pynsent PB (2011) Birmingham hip resurfacing: a minimum follow-up of ten years. J Bone Joint Surg Br 93(1):27-33. doi:10.1302/0301-620X.93B1.24134

9. Langton DJ, Jameson SS, Joyce TJ, Gandhi JN, Sidaginamale R, Mereddy P, Lord J, Nargol AV (2011) Accelerating failure rate of the ASR total hip replacement. J Bone Joint Surg Br 93(8):10111016. doi:10.1302/0301-620X.93B8.26040

10. Willert HG, Buchhorn GH, Fayyazi A, Flury R, Windler M, Koster G, Lohmann CH (2005) Metal-on-metal bearings and hypersensitivity in patients with artificial hip joints. A clinical and histomorphological study. J Bone Joint Surg Am 87(1):2836. doi:10.2106/JBJS.A.02039pp

11. Langton DJ, Jameson SS, Joyce TJ, Hallab NJ, Natu S, Nargol AV (2010) Early failure of metal-on-metal bearings in hip resurfacing and large-diameter total hip replacement: a consequence of excess wear. J Bone Joint Surg Br 92(1):38-46. doi:10.1302/0301-620X.92B1.22770

12. Liddle AD, Satchithananda K, Henckel J, Sabah SA, Vipulendran KV, Lewis A, Skinner JA, Mitchell AW, Hart AJ (2013) Revision of metal-on-metal hip arthroplasty in a tertiary center: a prospective study of 39 hips with between 1 and 4 years of follow-up. Acta Orthop 84(3):237-245. doi:10.3109/17453674.2013.797313

13. Randelli F, Banci L, Favilla S, Maglione D, Aliprandi A (2013) Radiographically undetectable periprosthetic osteolysis with ASR implants: the implication of blood metal ions. J Arthroplasty 28(8):1259-1264. doi:10.1016/j.arth.2013.02.019

14. Meyer H, Mueller T, Goldau G, Chamaon K, Ruetschi M, Lohmann $\mathrm{CH}$ (2012) Corrosion at the cone/taper interface leads to failure of large-diameter metal-on-metal total hip arthroplasties. Clin Orthop Relat Res 470(11):3101-3108. doi:10.1007/ s11999-012-2502-5

15. Nawabi DH, Gold S, Lyman S, Fields K, Padgett DE, Potter HG (2013) MRI predicts ALVAL and tissue damage in metal-onmetal hip arthroplasty. Clin Orthop Relat Res 472(2):471-481. doi:10.1007/s11999-013-2788-y

16. Nawabi DH, Hayter CL, Su EP, Koff MF, Perino G, Gold SL, Koch KM, Potter HG (2013) Magnetic resonance imaging findings in symptomatic versus asymptomatic subjects following metal-on-metal hip resurfacing arthroplasty. J Bone Joint Surg Am 95(10):895-902. doi:10.2106/JBJS.K.01476

17. Garcia-Cimbrelo E, Tapia M, Martin-Hervas C (2007) Multislice computed tomography for evaluating acetabular defects in revision THA. Clin Orthop Relat Res 463:138-143

18. Puri L, Wixson RL, Stern SH, Kohli J, Hendrix RW, Stulberg SD (2002) Use of helical computed tomography for the assessment of acetabular osteolysis after total hip arthroplasty. J Bone Joint Surg Am 84-A(4):609-614

19. Walde TA, Weiland DE, Leung SB, Kitamura N, Sychterz CJ, Engh CA Jr, Claus AM, Potter HG, Engh CA Sr (2005) Comparison of CT, MRI, and radiographs in assessing pelvic osteolysis: a cadaveric study. Clin Orthop Relat Res 437:138-144

20. Amstutz HC, Le Duff MJ, Campbell PA, Gruen TA, Wisk LE (2010) Clinical and radiographic results of metal-onmetal hip resurfacing with a minimum ten-year follow-up. J Bone Joint Surg Am 92(16):2663-2671. doi:10.2106/JBJ S.I.0171592/16/2663

21. DeLee JG, Charnley J (1976) Radiological demarcation of cemented sockets in total hip replacement. Clin Orthop Relat Res 121:20-32

22. Claus AM, Engh CA Jr, Sychterz CJ, Xenos JS, Orishimo KF, Engh CA Sr (2003) Radiographic definition of pelvic 
osteolysis following total hip arthroplasty. J Bone Joint Surg Am 85-A(8):1519-1526

23. Bolland BJ, Culliford DJ, Langton DJ, Millington JP, Arden NK, Latham JM (2011) High failure rates with a large-diameter hybrid metal-on-metal total hip replacement: clinical, radiological and retrieval analysis. J Bone Joint Surg Br 93(5):608-615. doi:10.1302/0301-620X.93B5.26309

24. Collier JP, Surprenant VA, Jensen RE, Mayor MB, Surprenant HP (1992) Corrosion between the components of modular femoral hip prostheses. J Bone Joint Surg Br 74(4):511-517

25. Gilbert JL, Buckley CA, Jacobs JJ (1993) In vivo corrosion of modular hip prosthesis components in mixed and similar metal combinations. The effect of crevice, stress, motion, and alloy coupling. J Biomed Mater Res 27(12):1533-1544. doi:10.1002/ jbm.820271210

26. Goldberg JR, Gilbert JL (2003) In vitro corrosion testing of modular hip tapers. J Biomed Mater Res B Appl Biomater 64(2):7893. doi: $10.1002 / \mathrm{jbm} . b .10526$

27. Grupp TM, Weik T, Bloemer W, Knaebel HP (2010) Modular titanium alloy neck adapter failures in hip replacement-failure mode analysis and influence of implant material. BMC Musculoskelet Disord 11:3. doi:10.1186/1471-2474-11-3

28. Kop AM, Swarts E (2009) Corrosion of a hip stem with a modular neck taper junction: a retrieval study of 16 cases. J Arthroplast 24(7):1019-1023. doi:10.1016/j.arth.2008.09.009

29. Hallab NJ, Messina C, Skipor A, Jacobs JJ (2004) Differences in the fretting corrosion of metal-metal and ceramic-metal modular junctions of total hip replacements. J Orthop Res 22(2):250-259. doi:10.1016/S0736-0266(03)00186-4

30. Higgs GB, Hanzlik JA, Macdonald DW, Gilbert JL, Rimnac CM, Kurtz SM, The Implant Research Center Writing C (2013) Is increased modularity associated with increased fretting and corrosion damage in metal-on-metal total hip arthroplasty devices?: a retrieval study. J Arthroplast. doi:10.1016/j.arth.2013.05.040

31. Holland JP, Langton DJ, Hashmi M (2012) Ten-year clinical, radiological and metal ion analysis of the Birmingham hip resurfacing: from a single, non-designer surgeon. J Bone Joint Surg Br 94(4):471-476. doi:10.1302/0301-620X.94B4.27895 